\title{
Mesenchymal Stem Cell Migration during Bone Formation and Bone Diseases Therapy
}

\author{
Peihong Su 1,2,3,+ (D), Ye Tian ${ }^{1,2,3,+}$, Chaofei Yang ${ }^{1,2,3}$, Xiaoli Ma ${ }^{1,2,3}$, Xue Wang ${ }^{1,2,3}$, \\ Jiawei Pei ${ }^{1,2,3}$ and Airong Qian 1,2,3,* (D) \\ 1 Lab for Bone Metabolism, Key Lab for Space Biosciences and Biotechnology, School of Life Sciences, \\ Northwestern Polytechnical University, Xi'an 710072, China; suph@mail.nwpu.edu.cn (P.S.); \\ Tianye@nwpu.edu.cn (Y.T.); chaofei-yang2015@mail.nwpu.edu.cn (C.Y.); \\ xiaoli225@mail.nwpu.edu.cn (X.M.); Wangxue1005@mail.nwpu.edu.cn (X.W.); pjwnwnu@163.com (J.P.) \\ 2 Research Center for Special Medicine and Health Systems Engineering, School of Life Sciences, \\ Northwestern Polytechnical University, Xi'an 710072, China \\ 3 NPU-UAB Joint Laboratory for Bone Metabolism, School of Life Sciences, Northwestern Polytechnical \\ University, Xi'an 710072, China \\ * Correspondence: qianair@nwpu.edu.cn; Tel.: +86-29-8849-1840 \\ + These authors contribute equally to this work.
}

Received: 5 June 2018; Accepted: 6 August 2018; Published: 9 August 2018

\begin{abstract}
During bone modeling, remodeling, and bone fracture repair, mesenchymal stem cells (MSCs) differentiate into chondrocyte or osteoblast to comply bone formation and regeneration. As multipotent stem cells, MSCs were used to treat bone diseases during the past several decades. However, most of these implications just focused on promoting MSC differentiation. Furthermore, cell migration is also a key issue for bone formation and bone diseases treatment. Abnormal MSC migration could cause different kinds of bone diseases, including osteoporosis. Additionally, for bone disease treatment, the migration of endogenous or exogenous MSCs to bone injury sites is required. Recently, researchers have paid more and more attention to two critical points. One is how to apply MSC migration to bone disease therapy. The other is how to enhance MSC migration to improve the therapeutic efficacy of bone diseases. Some considerable outcomes showed that enhancing MSC migration might be a novel trick for reversing bone loss and other bone diseases, such as osteoporosis, fracture, and osteoarthritis (OA). Although plenty of challenges need to be conquered, application of endogenous and exogenous MSC migration and developing different strategies to improve therapeutic efficacy through enhancing MSC migration to target tissue might be the trend in the future for bone disease treatment.
\end{abstract}

Keywords: mesenchymal stem cells; migration; bone formation; bone diseases; therapy

\section{Introduction}

Bone is a highly organized, dynamic, and vascularized connective tissue. The function of bone tissue is affected by many factors, such as hormones, growth factors, and mechanical loading. Recent research showed that the microstructure is also a basis of bone function, which governs the mechanical function of bone [1,2]. The microstructure of bone tissue is the orientation distribution and alignment of the density of biological apatite (BAp) crystallites. It is determined by the directional behaviors of bone cells, for example cell migration and cell arrangement [3]. Ozasa et al. found that artificially controlled direction of mesenchymal stem cells (MSC) migration and osteoblast alignment could reconstruct the microstructure of bone tissue, which led to appropriated bone formation during bone remodeling and regeneration [4]. 
Bone formation is important for bone health maintenance. It is conducted by MSC-derived osteogenic cells during bone modeling, remodeling, and fractured bone regeneration [5]. Generally, bone is formed by endochondral or intramembranous ossification. For most bones in the human skeleton, they are formed by endochondral ossification, including long, short, and irregular bones. In this case, MSCs firstly experience condensation and then differentiate into chondrocytes to form the cartilage growth plate and then the growth plate is gradually replaced by new bone, while other bones, such as skull, facial bones, and pelvis, are generated by intramembranous ossification, in which MSCs directly differentiate to osteoblasts [6,7].

MSC migration is the incipient step of bone formation because MSCs need to firstly migrate to the bone surface and then participate in bone formation process although MSCs differentiation into osteogenic cells is also a pivotal step. In the recent decades, MSC migration during bone formation has attracted more and more attention. Some studies show that MSC migration to the bone surface is crucial for bone formation and bone fracture healing. Abnormal migration of MSCs will lead to a homeostasis imbalance of bone. However, the mechanism of regulation of MSC migration remains unclear because cell migration is a complex and multi-step physiological process. Additionally, to date, there is no significant molecular marker for migration, so assessment of MSC migration in vivo is difficult. In this article, we drew an overview of MSC migration and regulation in bone formation during skeleton development or bone fracture healing. Moreover, recent approaches in the application of MSC migration in different bone disease therapies are summarized as well. Finally, the strategies of enhancing MSC migration and the perspective trend of bone disease therapies in the future are introduced. This review will provide a deeper understanding of MSC migration in vitro and in vivo and give guidance for the future research on bone formation and bone regeneration.

\section{The Overview of MSC Migration during Bone Formation}

\subsection{The Skeleton System is Developed through Two Types of Bone Formation}

The niches for MSCs locate adjacent to vessel walls, on the endosteal surfaces of trabecular bone, within the interfibrillary spaces [8]. A small amount of MSCs were also found in umbilical cord blood, dental tissues and synovial fluid [9]. Bone marrow and periosteum are the main sources of MSCs that participate in bone formation and are always used in skeletal repair clinically [10].

For endochondral ossification, MSCs are first condensed to initiate cartilage model formation. A part of MSCs, the cells in the center of the condensation, differentiate into chondrocytes and secrete cartilage matrix. Other MSCs, the cells at the periphery, form the perichondrium that continues expressing type I collagen and other important factors, such as proteoglycans and alkaline phosphatase (ALP) [11,12]. Then all chondrocytes undergo rapid proliferation. Chondrocytes in the center become maturation, accompanied with an invasion of hypertrophic cartilage by the vasculature, followed by differentiation of osteoblasts within the perichondrium and marrow cavity [13]. The inner perichondrium cells differentiate into osteoblasts, which secrete bone matrix to form the bone collar after vascularization in the hypertrophic cartilage [14]. Endochondral ossification is regulated by plenty of factors, such as growth factors (GFs), transforming growth factor- $\beta$ (TGF- $\beta$ ) and Sry-related high-mobility group box 9 (Sox9) [15-17]. Cell-to-cell interaction is also important to endochondral ossification [18].

For intramembranous ossification, MSCs firstly differentiate into preosteoblasts which proliferate near the bone surface and secrete ALP. Then they become mature osteoblasts and ultimately form osteocytes embedded in an extracellular matrix (ECM) [19]. Numerous factors, such as Runx2, special AT-rich sequence binding protein 2 (SATB 2), and osterix, and pathways, like the wnt/ $\beta$-catenin pathway and bone morphogenetic protein (BMP) pathway, regulate the intramembranous ossification of MSCs [20]. 


\subsection{MSC Migration Initiates Endochondral Ossification}

During endochondral ossification, MSC migration is involved in the initial condensation stage. The process is mediated by BMPs through phosphorylating and activating receptor SMADs to transduce signals [21]. Additionally, Hoxa13 and Hoxd13 have been reported to control MSC condensation in mouse bone formation. Hoxa13 and Hoxd13 deficiency induced a failure of cell-cell adhesion and inhibition of MSC condensation in mouse embryos [22]. It was also reported that cartilaginous ECM regulated cartilage formation by self-assembling MSCs. Furthermore, Type I and type II collagen promoted the cartilage disc formation through self-assembling MSCs. Without the ECM coating, MSCs would form dome-shaped pellets [23].

\subsection{Intramembranous Ossification is Accompanied with MSC Migration}

For intramembranous ossification, MSCs undergo proliferation and differentiation along the osteoblastic lineage to form bone directly without first forming cartilage. MSC and preosteoblast migration is involved in this process and are mediated by plentiful factors in vivo and in vitro (Figure 1). LL-37, a natural antimicrobial peptide that was found in the wound bed, could promote the migration of human adipose-derived stromal/stem cells (ASCs) which were isolated from subcutaneous adipose tissue through increasing the expression of early growth response 1 (EGR1) and activation of mitogen-activated protein kinases (MAPKs) [24]. Platelet-derived growth factors (PDGFs) is another essential molecule in skeletal development and bone fracture healing. PDGF-AA, which activates BMP-Smad1/5/8 signaling by feedback down-regulating PDGFRa, promotes mice primary bone marrow stromal cell (BMSC) migration via the BMP-Smad1/5/8-Twist1/Atf4 axis during intramembranous ossification [25]. Active transforming growth factor-beta 1 (TGF- $\beta 1$ ), released during bone resorption, recruits MSCs to the bone resorptive sites, is mediated through SMAD signaling pathway as well [26]. Additionally, matrix metalloproteinases (MMPs) are involved in regulating cancer cell migration and leukocyte homing and their deficiency inhibits primary human MSC migration [27,28]. Interestingly, MSC migration is always changed during its differentiation. In brief, the MSC migration is transiently up-regulated at early stage of bone formation and decreased at the later stage accompanied by an increased adhesiveness. This change may be induced by the altering of the activities of Rho-family small guanosine triphosphatase (GTP) ases and phosphorylation level of focal adhesion kinase (FAK) [29] (Table 1).

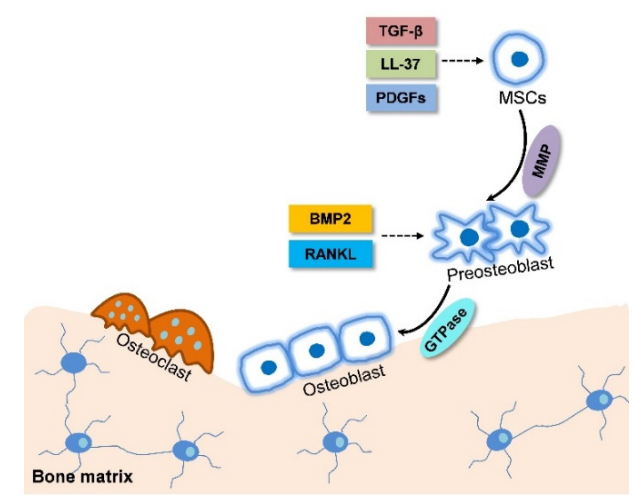

Figure 1. Schematic diagram of mesenchymal stem cell (MSC) migration during intramembranous ossification. LL-37, platelet-derived growth factors (PDGFs), and Transforming growth factor- $\beta$ (TGF- $\beta$ ) released from bone resorption surface and the high expression of Matrix metalloproteinases (MMP) in MSCs promote their migration to the site near bone surface. At the same time, MSCs differentiate into preosteoblast. Bone morphogenetic protein (BMP) and receptor activator of the nuclear factor kappa B ligand RANKL accelerate preosteoblast migration to the bone surface and the high expression of guanosine triphosphatase (GTPase) in preosteoblast promote cell migration. The solid arrows refer to cell migration. The dotted arrows refer to the effect of chemokine on MSC migration. 
Moreover, osteoblast migration into bone pits is also required for bone formation. During this process a large number of elements are involved in the regulation of osteoblast migration (Figure 1). As a GTPase, dynamin is used in several cellular activities including cell migration [30]. The GTPase activity of dynamin enhances early murine calvarial osteoblast differentiation to mature osteoblasts by increasing ALP activity and decreasing osteoblast migration [31,32]. The receptor activator of the nuclear factor kappa B ligand (RANKL) is another factor mediating osteoblast migration. It induces chemotactic migration of the human osteoblast cell line hFOB 1.19 and the primary human osteoblast through activating phosphorylation of extracellular signal-regulated kinase (ERK), p38 (MAPK), Akt, and p65 (NF-kB) [33]. Furthermore, BMP-2 could stimulate in vitro migration of the human primary osteoblasts isolated from trabecular bone in a dose-dependent manner, suggesting BMP-2 might be involved in the chemotactic recruitment of osteoblasts during bone formation in addition to its function as a differentiation enhancer [34] (Table 1).

\subsection{MSC Migration Induces Fracture Healing through Combining Endochondral Ossification and Intramembranous Ossification}

Endochondral ossification and intramembranous ossification are usually combined during bone formation of fracture healing and bone repair after bone injury. Ossification occurs under the periosteum within a few days after injury, while the endochondral ossification occurs adjacent to the fracture site lasts a period of up to 28 days [35].

MSC migration is critical for bone fracture healing because the bone repair process demands MSC migrate to the bone injury site in the first place to participate in bone formation. The recruitment of MSCs is initiated by the response of MSCs to inflammatory factors released from the bone fracture site. The biological process of MSC migration during bone repair is tightly regulated by signaling molecules, including growth factors, pro-inflammatory cytokines, and angiogenic factors [36]. Tan et al. provided the first evidence of the in vivo influence of endogenous PDGFs on the MSCs pool in humans. They found that PDGFs promoted endogenous MSC migration to the fracture site from remote sites [37]. Moreover, inflammatory mediators secreted by immune cells, such as macrophages and natural killer (NK) cells, are able to stimulate MSC recruitment [38,39] (Figure 2). For example, tumor necrosis factor alpha (TNF $\alpha$ ) promotes cultured BMSC migration to the target site leading to a bone formation increase via inducing the secretion of leucine-rich-alpha-2-glycoprotein1 (LRG1) [40]. Chemokine (C-X-C motif) ligand 7 (CXCL7), secreted by resting human NK cells, is capable of promoting primary BMSC migration. Additionally, the expression of other chemokines, such as stromal cell-derived factor-1 alpha (SDF- $1 \alpha)$ is up-regulated at the injury sites after fracture. SDF- $1 \alpha$ serves as a chemoattractant to recruit circulating or residing CXCR4-expressing MSCs to bone fracture sites, which leads to bone repair [41] (Table 1). SDF-1 $\alpha$ can also mediate MSC recruitment to the injury site through affecting the expression of some factors, such as Fms-related tyrosine kinase 3 (Flt3) ligand, stem cell factor (SCF), and hepatocyte growth factor (HGF) [42,43]. 
Table 1. Factors and pathways that affect MSC migration during bone formation.

\begin{tabular}{|c|c|c|c|c|c|}
\hline Factor & Ossification Pattern & Pathway & Efficacy & In Vitro or In Vivo & Reference \\
\hline BMPs & Endochondral & $\begin{array}{l}\text { Activate SMADs receptor to } \\
\text { transduce signals }\end{array}$ & $\begin{array}{c}\text { MSC condensation } \uparrow \\
\text { Recruitment of osteoblast } \uparrow\end{array}$ & In vitro & [21] \\
\hline $\begin{array}{l}\text { Hoxa13 and } \\
\text { Hoxd13 }\end{array}$ & Endochondral & Promote cell-cell adhesion & $\begin{array}{c}\text { MSC condensation } \uparrow \\
\text { Bone formation } \uparrow\end{array}$ & In vitro & [22] \\
\hline ECM & Endochondral & Self-assembling of MSCs & MSC condensation $\uparrow$ & In vitro & [23] \\
\hline LL-37 & Intramembranous & MAPK pathway & $\begin{array}{l}\text { Expression of EGR1 } \uparrow \\
\text { Activation of MAPKs }\end{array}$ & In vitro and in vivo & [24] \\
\hline PDGFs & Intramembranous & BMP-Smad1/5/8-Twist1/Atf4 axis & Cell migration $\uparrow$ & In vitro & [25] \\
\hline TGF- $\beta 1$ & Intramembranous & SMAD signaling & Cell migration $\uparrow$ & In vitro and in vivo & [26] \\
\hline MMP & Intramembranous & Penetrate blood vessel basement membranes & Induce MSC migration & In vitro and in vivo & {$[27,28]$} \\
\hline NF- $\kappa B$ ligand & Intramembranous & Activating phosphorylation of ERK, MAPK, Akt, and NF- $k B$ & Cell migration $\uparrow$ & In vitro & {$[33]$} \\
\hline $\mathrm{TNF} \alpha$ & Fracture healing & Induce LRG1 secretion & MSC recruitment $\uparrow$ & In vitro and in vivo & [40] \\
\hline CXCL7 & Fracture healing & Binding CXCR2 & MSC recruitment $\uparrow$ & In vitro & [36] \\
\hline SDF-1 & Fracture healing & Binding CXCR4 & $\begin{array}{c}\text { Osteoblast migration } \uparrow \\
\text { MSC recruitment } \uparrow\end{array}$ & In vitro and in vivo & [41] \\
\hline
\end{tabular}

^: Up-regulation. 


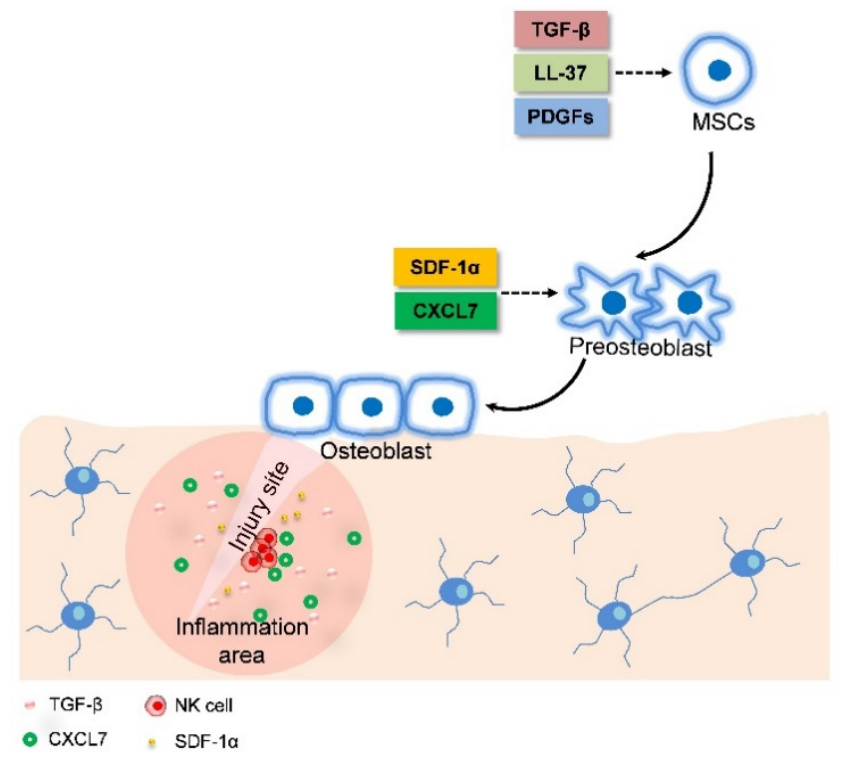

Figure 2. Schematic diagram of MSC migration during fracture healing. LL-37, PDGFs, and TGE- $\beta$ from the inflammation area promote MSCs migrate to the site near the bone surface. At the same time, MSCs differentiated into preosteoblasts. SDF-1 $\alpha$ and CXCL7 released from the bone injury site enhances preostelast migration to the bone surface. At the same time, preosteoblasts differentiate into osteoblasts. The solid arrows refer to cell migration. The dotted arrows refer to the effect of chemokines on MSC migration.

\section{The Application of MSC Migration in Bone Disease Therapy}

Bone is constantly in a balance of bone formation and resorption mediated by osteoblasts and osteoclasts, respectively. Bone diseases, such as osteoporosis and nonunion, occur when the balance is disrupted. Bone-forming osteoblasts are derived from MSCs which are recruited to the bone surface and then differentiate into osteogenic cells to form new bone. Haasters et al. have shown, for the first time, a significantly reduced migration of hMSCs separated from osteoporotic patients when cells were stimulated using BMP-2 or BMP-7 [44]. Meanwhile, the MSCs derived from the femurs of aged and ovariectomised rats showed impaired migration, which might be associated with the significant decrease in bone formation [45]. Additionally, a large number of studies have suggested that fracture healing was significantly delayed in osteoporotic patients [46]. Therefore, we can easily conclude the importance of MSC migration in bone regeneration and fracture healing. Additionally, we have reasons to believe that the reduction of MSC migration may be a potential mechanism underlying the fracture delay in osteoporotic patients, which may provide a new thinking for treatment of fracture, osteoporosis, and other bone diseases.

\subsection{Treatment of Osteoporosis}

Actually, the roles of MSC migration on treatment of bone diseases have been investigated by more and more researchers in recent years. Effective homing is essential for MSC function and integration to target tissue and greatly enhances reversion of bone loss [47]. It has been reported that the transplantation of mouse $\mathrm{C} 3 \mathrm{H} 10 \mathrm{~T} 1 / 2$ cells expressing human CXCR4 and Cbfa-1 (core binding factora-1, also called Runx2)-increased MSC homing. Further studies have shown that this transplantation promoted bone formation and restored bone mass in osteoporotic mice model after four weeks of transplantation [48]. Additionally, primary BMSC transplantation has been used to treat severe osteogenesis imperfecta clinically, though only short-term clinical improvement was observed in some patients [49]. Exogenous MSC transplantation exhibits promising outcomes, however, directing endogenous MSCs to the bone surface may be a better choice for osteoporosis 
treatment. Guan et al. have developed a synthetic high affinity and specific peptidomimetic ligand 1 (LLP2A) which has high affinity for bone to direct the MSCs to the bone surface. In vitro study showed that LLP2A treatment enhanced primary MSC migration. In vivo study demonstrated that trabecular bone formation and bone mass of mice were increased after single intravenous injection of LLP2A [50]. Those studies provide direct proof that increasing MSC migration could be a new strategy for osteoporosis therapy (Table 2).

\subsection{Bone Fracture Healing}

Bone fracture is one of the most prevalent clinical issues in our aging society. MSCs play a pivotal role in bone repair after fracture [51]. Obermeyer et al. have reported that endogenous and transplanted primary BMSCs were capable of especially homing to the fracture site and then started to restore both the fracture callus volume and the biomechanical strength of the bone when fluorescence-labeled MSCs were transplanted intravenously to a mouse fracture model $[52,53]$. Furthermore, Zwingenberger et al. reported that the combination of low dose BMP-2 and SDF- $1 \alpha$ can promote the rate of bone healing by increasing transplanted primary MSC recruitment to injury site. Their further study suggested that SDF- $1 \alpha$ and BMP-2 in combination at the defect site could increase bone volume and the ratio of osteoblasts to osteoclasts which represents a trend toward more bone formation [54]. A similar result was obtained by Chen et al. when they investigated the joint effects of MSCs with SDF- $1 \alpha$ on bone formation in nonunion rat model [55]. It was also reported that Sox11 overexpression enhanced rat primary BMSC migration in vitro and in vivo and improved bone fracture healing when the MSCs with Sox11 overexpression were injected into a rat model with open femur fracture through the tail vein [56] (Table 2).

\subsection{Therapy for Other Bone Diseases}

MSC migration is also essential for treatment of other bone diseases, such as OA and periodontitis. It was reported that primary ASC migration was enhanced by overexpressing sRAGE, a truncated form of the receptor for advanced glycation end products (RAGE). The injection of sRAGE-ASCs into the base of the tail of OA mice model decreased Th17 cells and increased regulatory $\mathrm{T}$ cells, which indicated sRAGE-ASCs exerted great therapeutic activity in vivo to OA [57]. Additionally, periodontitis may also associate with a lesser number and impaired function of MSCs. Han et al. found that insulin-like growth factor binding protein 5 (IGFBP5) rescued the impaired function of primary periodontal ligament stem cells (PDLSCs). Local injection of recombined IGFBP5 to periodontal tissue could enhance tissue regeneration and relieve the local inflammation in periodontitis mode [58]. Moreover, parathyroid hormone (PTH) was reported to promote bone repair by activating MSCs. PTH injection therapy via ear vein enhanced injected primary hMSC migration to lumbar region, where the MSCs differentiated into osteogenic cells and increased new bone formation significantly in vertebral defect rat models [59]. However, in certain situation, increased MSC migration is associated with bad prognosis. For example, MSC migration to subchondral bone induced by over-active TGF- $\beta 1$ accelerated progression of OA. On the other hand, suppressed TGF- $\beta 1$ activity in the subchondral bone may have a beneficial effect to OA [60-62]. Although some downside exists, promoting MSC migration is still a potential therapy for many bone diseases. Increasing MSC migration will be a novel method for treatment of those diseases and reduce the delayed bone healing (Table 2). 
Table 2. Clinical applications of MSC migration in the enhancement of bone regeneration and bone repair.

\begin{tabular}{|c|c|c|c|c|}
\hline MSCs & Administration & Diseases & Efficacy & Reference \\
\hline C3H10T1/2 & Intravenous injection & Osteoporosis & Restoration bone formation and bone mass & [48] \\
\hline BM-MSCs & Bone marrow transplantation & Osteogenesis imperfecta & Bone mineralization density $\uparrow$ & [49] \\
\hline Endogenous MSCs & Intravenous injection of LLP2A & Impairment of osteogenesis & Trabecular bone formation bone mass $\uparrow$ & [50] \\
\hline Primary BM-MSCs & Intravenous transplant & Tibia fracture & $\begin{array}{l}\text { Restoration both fracture callus volume and } \\
\text { biomechanical strength }\end{array}$ & {$[52,53]$} \\
\hline Endogenous MSCs & $\begin{array}{l}\text { Implantation of fat tissue grafts } \\
\text { expressing SDF- } 1 \alpha \text { or/and BMP-2 }\end{array}$ & Bone defect & Bone formation $\uparrow$ & [49] \\
\hline Primary MSCs sheet & Local injection & Nonunion & Bone fracture healing $\uparrow$ Inflammatory arthritis $\downarrow$ & [55] \\
\hline Primary GFP-MSCs & Tail vein injection & Femur fracture & $\begin{array}{c}\text { Local inflammation } \downarrow \text { periodontal tissue } \\
\text { regeneration } \uparrow\end{array}$ & [56] \\
\hline sRAGE-ASCs & Tail vein injection & $\mathrm{OA}$ & Local inflammation $\downarrow$ & [57] \\
\hline PDLSCs & Local injection of IGFBP5 & Periodontitis & MSC migration $\uparrow$ & [58] \\
\hline HMSCs & Injection via ear vein & Vertebral defect & New bone formation $\uparrow$ & [59] \\
\hline
\end{tabular}

^: Up-regulation; $\vee$ : Down-regulation. 


\section{Enhancing MSC Migration is a New Strategy for Improving the Efficacy of Bone Disease Treatment}

The modes of administration of MSCs in bone diseases therapy include systemic administration, such as intravenous (IV) or intra-arterial (IA) injection, and local administration, such as intracoronary (IC) injection or direct injection into the target tissue. However, the therapeutic efficacy of bone diseases is relatively low. For example, for the systemic administration, only a small percentage of MSCs can approach the target tissue [63]. Therefore, promoting MSC migration and homing could be a solution for therapeutic efficacy improvement of bone diseases. Several strategies are under development (Table 3).

\subsection{Pretreatment of MSCs in Culture}

During MSC's expansion in vitro, the expression level of some crucial molecules, such as CXCR4, a key regulator in MSC migration and homing by interaction with appropriate ligands, are downregulated [64]. It was reported that MSCs seems to lose this migration and homing regulator expression during in vitro culture process $[65,66]$. To maintain the expression of those molecules, much effort has been made. One way is to add cytokines or cytokine cocktails in culture medium during expansion. Shi et al. showed that both the intracellular and membrane expression of CXCR4 in cultured primary MSCs, which were derived from human fetal bone marrow were increased by the pretreatment of a combination of Flt3 ligand, SCF, and HGF. Moreover, a significant increase in bone marrow homing of the primary MSCs has been observed after cytokine treatment [67]. Additionally, pretreatment with GSK-3 $\beta$ inhibitors or complement 1q (C1q) increased MMP expression in primary hMSCs, which are important for the degradation of the basement membrane during MSC homing [68,69].

Another way to improve MSC migration is culturing cells under hypoxic conditions. It has been reported that hypoxic conditions decreased the MMP secretion and increased the MT1-MMP secretion and activity when mouse primary BMSCs were cultured in vitro [70]. Moreover, several studies also showed that hypoxic condition led to CXCR4 expression in primary BMSCs and cell migration were promoted both in vitro and in vivo [71].

Exposure to certain chemicals could also trigger the expression of key factors involved in MSC migration and homing. Tsai et al. found that valproate or lithium treatment of cultured MSCs resulted in robust cell migration and homing. This kind of treatment accelerated function recovery of brain, as well when the MSCs were transplanted into a rat model of cerebral ischemia [72]. Additionally, deferoxamine (DFO) has been reported to increase expression of CXCR4 and chemokine receptor 7 (CCR7) protein in MSC membrane. Further studies both in vitro and in vivo indicated that DFO treatment increased primary MSC migration and homing when cells were injected into the tail vein of rat [73]. Cobalt chloride and hydralazine had similar effects on mouse primary BMSC migration and homing, which made them become cell migration-promoting components [74-76] (Table 3).

\subsection{Genetic Modifications of MSCs or Target Tissue}

Using genetic modification methods to increase the expression of key regulators seem to be possible and feasible strategies to improve MSC migration. Overexpression of CXCR4 and integrin $\beta 4$ using virus or plasmid transfection into primary MSCs resulted in improved cell migration and homing $[77,78]$. However, not all genetic modification of MSCs can promote cell migration. Wiehe et al. found that no increase in migration of primary hMSCs derived from tibia and femur, as well as from pelvic bone marrow when CXCR4 was overexpressed in cells using mRNA nucleofection. Additionally, the cell viability of transfected MSCs was decreased to 62\% [79].

Usually, after tissue injury, the expression of some chemokines, such as SDF- $1 \alpha$, is increased in damaged cells, which leads to recruitment and retention of progenitor cells to the injury site [80]. Thus, an increase chemokine expression and secretion in injury tissue through transfection of chemokine encoding genes would be a promising idea to improving the efficacy of bone disease treatment [38]. This kind of strategy has been reported to be used to treat ischemic cardiomyopathy. A clinical 
trial that a plasmid encoding SDF-1 $\alpha$ was transfected into the endomyocardia of 17 patients to treat ischemic cardiomyopathy further proved the feasibility of such kind of method [81]. Similarly, Fujii et al. reported that the transfection of SCF and SDF- $1 \alpha$ into the myocardium of rat increased SDF- $1 \alpha$ expression at mRNA and protein levels and induced an increment of endogenous MSC migration consequently [82]. SDF- $1 \alpha$ can recruit stem cells and progenitor cells into an injured heart, which is similar with the role of SDF- $1 \alpha$ in bone regeneration, therefore, this strategy might be used to treat fractures [83-85]. While, in OA synovial fluid, the SDF- $1 \alpha$ levels were increased and it acted as a catabolic factor for cartilage homeostasis. Recent research reported that inhibition of SDF- $1 \alpha / C X C R 4$ signaling in post-traumatic OA mouse model induced partial prevention of bone loss cartilage degeneration [86]. Therefore, based on different diseases and variable clinical situations, comprehensive considerations should be made. The key issue is to choose the most suitable therapy and maximized patients' benefits. Another strategy to increase chemokine expression and secretion is to inject cells that express ectopic chemokine into target tissue. This strategy has been applied in the treatment of ischemic myocardium through the injection of SDF-1a overexpression primary BMSCs into tissue to promote endogenous bone marrow-derived progenitor migration to the injury site [87]. Furthermore, the strategy has also been used in the therapy of other diseases, such as the treatment of diabetic wounds, which provided essential clues to the promotion of efficacy of bone diseases treatment through improving MSC migration [88] (Table 3).

\subsection{Cell Surface Engineering}

Cells transmigrate through the activated endothelium in vivo is required for MSC migration and homing to target tissue. Interaction between molecules on the cell surface of MSCs and tissue is critical in the transmigration process. In recent years, cell surface engineering, i.e., a transient modification of the cell surface, has attracted much attention of researchers in improving homing efficiency of MSCs [89]. Most importantly, this kind of modification would not damage cell viability and function $[86,90]$. Based on this strategy, Sarkar et al. used biotinylated microvesicles to introduce Sialyl Lewis X (SLEX), the active site of P-selectin glycoprotein ligand-1 (PSGL-1), into cultured MSC membranes. In vitro research indicated that the expression of SLEX in the MSCs increased cell adhesion under shear stress [90]. Further study, in which the first 19 amino acids of PSGL-1 (Fc19) was combined with SLEX to construct a pan-selectin-binding ligand, had a similar result [87]. Additionally, primary MSC migration was significantly improved by the use of cell surface engineering to convert the native CD44 in MSC membranes into the hematopoietic cell E-selectin/L-selectin ligand (HCELL) [90].

Conjugating antibodies to the cell surface is another interesting technique to improve MSC migration to target tissue. Using the technique, vascular cell adhesion molecule 1 (VCAM-1) antibodies were bound to a mouse-cultured MSC surface. It was proved that the binding could improve MSC homing to bone marrow [91]. Of course, this technique has also been used to improve MSC migration to other target tissue, such as lymph nodes and the colon [89] (Table 3).

Although there are many drawbacks of the methods mentioned above (Table 3), they indeed provide essential ideas to improve the efficacy of bone disease treatment. Only a few strategies introduced have been applied in bone disease treatment, but they imply that the efficacy of bone disease treatment could be improved through increasing MSC migration to injury sites by pretreatment of MSCs, genetic modification of MSCs, or target tissue and reconstruction of cells using cell surface engineering. 
Table 3. The advantages and drawbacks of strategies for improving MSC migration.

\begin{tabular}{|c|c|c|c|c|}
\hline Strategy & Advantages & Main Drawbacks & Example & Reference \\
\hline Treatment with cytokine or cytokine cocktail & Simple and fast & $\begin{array}{l}\text { Unwanted genes may be } \\
\text { expressed, expensive }\end{array}$ & $\begin{array}{l}\text { Pretreat MSCs with flt3 ligand, } \\
\text { stem cell factor (SCF) or } \\
\text { hepatocyte growth factor (HGF). } \\
\text { Pretreat with GSK3 } \beta \text { inhibitor }\end{array}$ & {$[67,68]$} \\
\hline Hypoxic condition & Simple and fast & $\begin{array}{l}\text { Cells probably migrate into } \\
\text { non-targeted organs }\end{array}$ & & {$[72,73]$} \\
\hline Treatment with compound & Intravenous injection of LLP2A & $\begin{array}{l}\text { Unwanted genes may be } \\
\text { expressed, expensive }\end{array}$ & $\begin{array}{l}\text { Treatment MSCs Valproate or } \\
\text { lithium }\end{array}$ & [74] \\
\hline Genetic modification of MSCs & More directed & $\begin{array}{c}\text { Difficult, expensive and risk } \\
\text { of tumorigenicity }\end{array}$ & $\begin{array}{c}\text { Overexpression of CXCR4 and } \\
\text { integrin } \beta 4\end{array}$ & {$[77,78]$} \\
\hline Genetic modification of injury tissue & Targeted & $\begin{array}{c}\text { Immunogenicity, } \\
\text { Retroviral-mediated } \\
\text { insertional mutagenesis }\end{array}$ & $\begin{array}{l}\text { Transfection of SDF-1 plasmid } \\
\text { to injury tissue }\end{array}$ & [84] \\
\hline Injection of ectopic chemokine expressing cells & High efficiency & $\begin{array}{l}\text { Safety problems, difficult } \\
\text { and expensive }\end{array}$ & $\begin{array}{c}\text { Injection of SDF- } 1 \alpha \\
\text { overexpression MSCs into tissue }\end{array}$ & [85] \\
\hline Introduce certain protein expression & No damage for cell viability and function & $\begin{array}{c}\text { Safety problems, Difficult } \\
\text { and expensive, Risk of } \\
\text { tumorigenicity, }\end{array}$ & $\begin{array}{l}\text { Express SLEX on MSCs } \\
\text { membrane }\end{array}$ & [89] \\
\hline Coating of cell surface with antibodies & More targeted & Difficult and expensive & $\begin{array}{l}\text { Bind VCAM- } 1 \text { antibodies to } \\
\text { MSCs bone surface }\end{array}$ & [90] \\
\hline
\end{tabular}




\section{Conclusions}

For bone formation during bone modeling, remodeling and bone fracture repair, MSCs are the source of osteogenic cells. For bone disease treatment, MSCs are the ideal candidate due to their multipotential differentiation. Up to the present, the main studies about bone regeneration using MSCs are focused on osteogenic cell differentiation. However, based on the previous reports, aging and osteoporosis reduce the migration of MSCs which further induces a delay of fracture healing. More and more attention has been paid by researchers to the treatment of bone diseases by promoting MSC migration and some considerable outcomes have been achieved. Therefore, enhancing MSC migration is an important issue for bone formation and treatment of bone diseases. Additionally, it might be a novel target for bone disease therapy, such as osteoporosis and fracture repair, though there are still plenty of challenges that need to be faced.

MSC migration and differentiation are two important physiological processes in bone formation. Therefore, migration of stem cells alone is not sufficient. Both migration and differentiation of MSCs are required during bone remodeling and regeneration. Some factors that promote MSC migration could enhance its differentiation, such as IGF and high mobility group box 1 (HMGB1) [92,93], while others could inhibit MSC differentiation, such as dynamin [30,32,94,95]. Thus, it is necessary for us to discriminate the main reasons that cause bone disease and then adopt proper strategies to treat bone disease.

The existing data shows potential of MSC migration in bone diseases treatment. However, most of those studies are just limited in vitro studies, the in vivo data are still lacking, and the mechanism of MSC migration is not fully understood. Therefore, based on the application of MSC migration on the therapy of bone diseases, the future perspectives for bone regeneration may include: (1) construct fluorescence-labeled MSCs and observe MSC migration in real-time in vivo using imaging systems which could provide direct proof of MSC migration in vivo [46,96]; and (2) Use endogenous and native MSCs as the source of cells for bone diseases therapy since, firstly, endogenous MSCs avoid the immunocompatibility, second, endogenous treatment is an easier, safer, and more efficient method than exogenic cells, and third, with the smallest damage, no extra surgical procedure is introduced [97]; (3) Develop and try more strategies to improve the efficacy of bone diseases therapy through enhancing MSC migration and recruitment to the bone surface since MSCs used in current research are isolated from tissue, expanded in vitro and then transplanted back into animal through intravenous injection or local injection. Those processes significantly decrease the treatment efficiency.

Author Contributions: P.S. and Y.T. conceived the concept of this manuscript and wrote the first draft version of it, which was then equally developed by C.Y., X.M., J.P. and A.Q. revised and proofread the manuscript. All authors have read and approved the final submitted manuscript.

Funding: This work was funded by the National Natural Science Foundation of China (nos. 31570940, 81772017) and Natural Science Basic Research Plan in Shannxi Province of China (no. 2018JQ8032).

Conflicts of Interest: The authors declare no conflict of interest.

\section{Abbreviations}

$\begin{array}{ll}\text { ALP } & \text { Alkaline phosphatase } \\ \text { ASCs } & \text { Adipose-derived stromal/stem cells } \\ \text { BMPs } & \text { Bone morphogenic proteins } \\ \text { C1q } & \text { Complement 1q } \\ \text { CCR7 } & \text { Chemokine receptor 7 } \\ \text { CXCL7 } & \text { chemokine (C-X-C motif) ligand 7 } \\ \text { DFO } & \text { Deferoxamine } \\ \text { Erk } & \text { Extracellular signal-regulated kinase } \\ \text { Flt3 } & \text { Fms-related tyrosine kinase 3 } \\ \text { GFs } & \text { Growth factors }\end{array}$




$\begin{array}{ll}\text { GTPase } & \text { GTP hydrolase } \\ \text { HCELL } & \text { Haematopoietic cell E-selectin/L-selectin ligand } \\ \text { HGF } & \text { Hepatocyte growth factor } \\ \text { HMGB1 } & \text { High mobility group box 1 } \\ \text { IA } & \text { Intra-arterial } \\ \text { IC } & \text { Intracoronary } \\ \text { IGF } & \text { Insulin-like growth factor } \\ \text { IGFBP5 } & \text { Insulin-like growth factor binding protein } 5 \\ \text { IV } & \text { Intravenous } \\ \text { LRG1 } & \text { Leucine-rich-alpha-2-glycoprotein1 } \\ \text { MMP } & \text { Matrix metalloproteinases } \\ \text { NK } & \text { Natural killer } \\ \text { OA } & \text { Osteoarthritis } \\ \text { PDGFs } & \text { platelet-derived growth factors } \\ \text { PDLSCs } & \text { Primary period ligament stem cells } \\ \text { PSGL-1 } & \text { P-selectin glycoprotein ligand-1 } \\ \text { PTH } & \text { Parathyroid hormone } \\ \text { RAGE } & \text { Receptor for advanced glycation end } \\ \text { SATB 2 } & \text { Special AT-rich sequence binding protein } 2 \\ \text { SCF } & \text { Stem cell factor } \\ \text { SDF-1 } \alpha & \text { Stromal cell-derived factor-1 alpha; } \\ \text { SLEX } & \text { Sialyl Lewis X } \\ \text { Sox9 } & \text { Sry-related high-mobility group box } 9 \\ \text { TGF- } \beta & \text { Transforming growth factor- } \beta \\ \text { TNF } \alpha & \text { Tumor necrosis factor alpha } \\ \text { VCAM-1 } & \text { Vascular cell adhesion molecule 1 } \\ \text { VEGF } & \text { Vascular endothelial growth factor } \\ & \end{array}$

\section{References}

1. Schaff, F.; Bech, M.; Zaslansky, P.; Jud, C.; Liebi, M.; Guizar-Sicairos, M.; Pfeiffer, F. Six-dimensional real and reciprocal space small-angle X-ray scattering tomography. Nature 2015, 527, 353-356. [CrossRef] [PubMed]

2. Nakano, T.; Kaibara, K.; Ishimoto, T.; Tabata, Y.; Umakoshi, Y. Biological apatite (BAp) crystallographic orientation and texture as a new index for assessing the microstructure and function of bone regenerated by tissue engineering. Bone 2012, 51, 741-747. [CrossRef] [PubMed]

3. Gemini-Piperni, S.; Takamori, E.R.; Sartoretto, S.C.; Paiva, K.B.S.; Granjeiro, J.M.; de Oliveira, R.C.; Zambuzzi, W.F. Cellular behavior as a dynamic field for exploring bone bioengineering: A closer look at cell-biomaterial interface. Arch. Biochem. Biophys. 2014, 561, 88-98. [CrossRef] [PubMed]

4. Ozasa, R.; Matsugaki, A.; Isobe, Y.; Saku, T.; Yun, H.S.; Nakano, T. Construction of human induced pluripotent stem cell-derived oriented bone matrix microstructure by using in vitro engineered anisotropic culture model. J. Biomed. Mater. Res. Part A 2018, 106, 360-369. [CrossRef] [PubMed]

5. Luu, H.H.; Song, W.X.; Luo, X.; Manning, D.; Luo, J.; Deng, Z.L.; Sharff, K.A.; Montag, A.G.; Haydon, R.C.; He, T.C. Distinct roles of bone morphogenetic proteins in osteogenic differentiation of mesenchymal stem cells. J. Orthop. Res. Off. Publ. Orthop. Res. Soc. 2007, 25, 665-677. [CrossRef] [PubMed]

6. Yang, Y.Q.; Tan, Y.Y.; Wong, R.; Wenden, A.; Zhang, L.K.; Rabie, A.B.M. The role of vascular endothelial growth factor in ossification. Int. J. Oral Sci. 2012, 4, 64-68. [CrossRef] [PubMed]

7. Liu, T.M.; Lee, E.H. Transcriptional Regulatory Cascades in Runx2-Dependent Bone Development. Tissue Eng. Part B Rev. 2013, 19, 254-263. [CrossRef] [PubMed]

8. Scadden, D.T. The stem-cell niche as an entity of action. Nature 2006, 441, 1075-1079. [CrossRef] [PubMed]

9. Rodriguez-Lozano, F.J.; Bueno, C.; Insausti, C.L.; Meseguer, L.; Ramirez, M.C.; Blanquer, M.; Marín, N.; Martínez, S.; Moraleda, J.M. Mesenchymal stem cells derived from dental tissues. Int. Endod. J. 2011, 44, 800-806. [CrossRef] [PubMed]

10. Wang, X.; Wang, Y.; Gou, W.L.; Lu, Q.; Peng, J.; Lu, S.B. Role of mesenchymal stem cells in bone regeneration and fracture repair: A review. Int. Orthop. 2013, 37, 2491-2498. [CrossRef] [PubMed] 
11. Mackie, E.J.; Ahmed, Y.A.; Tatarczuch, L.; Chen, K.S.; Mirams, M. Endochondral ossification: How cartilage is converted into bone in the developing skeleton. Int. J. Biochem. Cell Biol. 2008, 40, 46-62. [CrossRef] [PubMed]

12. Foster, J.W.; Dominguez-Steglich, M.A.; Guioli, S.; Kwok, C.; Weller, P.A.; Stevanovic, M.; Weissenbach, J.; Mansour, S.; Young, I.D.; Goodfellow, P.N.; et al. Campomelic dysplasia and autosomal sex reversal caused by mutations in an SRY-related gene. Nature 1994, 372, 525-530. [CrossRef] [PubMed]

13. Long, F. Building strong bones: Molecular regulation of the osteoblast lineage. Nat. Rev. Mol. Cell Biol. 2011, 13, 27-38. [CrossRef] [PubMed]

14. Long, F.; Ornitz, D.M. Development of the endochondral skeleton. CSH Perspect. Biol. 2013, 5, a008334. [CrossRef] [PubMed]

15. Yu, D.A.; Han, J.; Kim, B.S. Stimulation of chondrogenic differentiation of mesenchymal stem cells. Int. J. Stem Cells 2012, 5, 16-22. [CrossRef] [PubMed]

16. Bian, L.M.; Zhai, D.Y.; Tous, E.; Rai, R.; Mauck, R.L.; Burdick, J.A. Enhanced MSC chondrogenesis following delivery of TGF-beta 3 from alginate microspheres within hyaluronic acid hydrogels in vitro and in vivo. Biomaterials 2011, 32, 6425-6434. [CrossRef] [PubMed]

17. Kawakami, Y.; Rodriguez-Leon, J.; Izpisua Belmonte, J.C. The role of TGF $\beta$ s and Sox9 during limb chondrogenesis. Curr. Opin. Cell Biol. 2006, 18, 723-729. [CrossRef] [PubMed]

18. Koga, H.; Muneta, T.; Nagase, T.; Nimura, A.; Ju, Y.J.; Mochizuki, T.; Sekiya, I. Comparison of mesenchymal tissues-derived stem cells for in vivo chondrogenesis: Suitable conditions for cell therapy of cartilage defects in rabbit. Cell Tissue Res. 2008, 333, 207-215. [CrossRef] [PubMed]

19. Maes, C.; Kobayashi, T.; Selig, M.K.; Torrekens, S.; Roth, S.I.; Mackem, S.; Carmeliet, G.; Kronenberg, H.M. Osteoblast precursors, but not mature osteoblasts, move into developing and fractured bones along with invading blood vessels. Dev. Cell 2010, 19, 329-344. [CrossRef] [PubMed]

20. Fakhry, M.; Hamade, E.; Badran, B.; Buchet, R.; Magne, D. Molecular mechanisms of mesenchymal stem cell differentiation towards osteoblasts. World J. Stem Cells 2013, 5, 136-148. [CrossRef] [PubMed]

21. Massague, J.; Seoane, J.; Wotton, D. Smad transcription factors. Genes Dev. 2005, 19, 2783-2810. [CrossRef] [PubMed]

22. Stadler, H.S.; Higgins, K.M.; Capecchi, M.R. Loss of Eph-receptor expression correlates with loss of cell adhesion and chondrogenic capacity in Hoxa13 mutant limbs. Development 2001, 128, 4177-4188. [PubMed]

23. Ng, J.; Wei, Y.; Zhou, B.; Burapachaisri, A.; Guo, E.; Vunjak-Novakovic, G. Extracellular matrix components and culture regimen selectively regulate cartilage formation by self-assembling human mesenchymal stem cells in vitro and in vivo. Stem Cell Res. Ther. 2016, 7, 183. [CrossRef] [PubMed]

24. Yang, Y.; Choi, H.; Seon, M.; Cho, D.; Bang, S.I. LL-37 stimulates the functions of adipose-derived stromal/stem cells via early growth response 1 and the MAPK pathway. Stem Cell Res. Ther. 2016, 7, 58. [CrossRef] [PubMed]

25. Cong, Q.; Yeh, J.; Xia, X.C.; Mishina, Y.; Hao, A.J.; Li, B.J. PDGF-AA promotes osteogenic differentiation and migration of mesenchymal stem cell by down-regulating PDGFRa and derepressing BMP-Smad1 signaling. PLoS ONE 2014, 9, e113785.

26. Tang, Y.; Wu, X.; Lei, W.; Pang, L.; Wan, C.; Shi, Z.; Zhao, L.; Nagy, T.R.; Peng, X.; Hu, J.; et al. TGF- $\beta 1$-induced migration of bone mesenchymal stem cells couples bone resorption with formation. Nat. Med. 2009, 15, 757-765. [CrossRef] [PubMed]

27. Faveeuw, C.; Preece, G.; Ager, A. Transendothelial migration of lymphocytes across high endothelial venules into lymph nodes is affected by metalloproteinases. Blood 2001, 98, 688-695. [CrossRef] [PubMed]

28. Guan, S.P.; Lam, A.T.L.; Newman, J.P.; Chua, K.L.M.; Kok, C.Y.L.; Chong, S.T.; Chua, M.L.K.; Lam, P.Y.P. Matrix metalloproteinase-1 facilitates MSC migration via cleavage of IGF-2/IGFBP2 complex. FEBS Open Bio 2018, 8, 15-26. [CrossRef] [PubMed]

29. Ichida, M.; Yui, Y.; Yoshioka, K.; Tanaka, T.; Wakamatsu, T.; Yoshikawa, H.; Itoh, K. Changes in cell migration of mesenchymal cells during osteogenic differentiation. FEBS Lett. 2011, 585, 4018-4024. [CrossRef] [PubMed]

30. Razidlo, G.L.; Wang, Y.; Chen, J.; Krueger, E.W.; Billadeau, D.D.; McNiven, M.A. Dynamin 2 Potentiates Invasive Migration of Pancreatic Tumor Cells through Stabilization of the Rac1 GEF Vav1. Dev. Cell 2013, 24, 573-585. [CrossRef] [PubMed] 
31. Taylor, M.J.; Lampe, M.; Merrifield, C.J. A Feedback Loop between Dynamin and Actin Recruitment during Clathrin-Mediated Endocytosis. PLoS Biol. 2012, 10, e1001302. [CrossRef] [PubMed]

32. Eleniste, P.P.; Huang, S.; Wayakanon, K.; Largura, H.W.; Bruzzaniti, A. Osteoblast differentiation and migration are regulated by Dynamin GTPase activity. Int. J. Biochem. Cell Biol. 2014, 46, 9-18. [CrossRef] [PubMed]

33. Golden, D.; Saria, E.A.; Hansen, M.F. Regulation of Osteoblast Migration Involving Receptor Activator of Nuclear Factor-kappa B (RANK) Signaling. J. Cell. Physiol. 2015, 230, 2951-2960. [CrossRef] [PubMed]

34. Lind, M.; Eriksen, E.F.; Bünger, C. Bone morphogenetic protein-2 but not bone morphogenetic protein- 4 and -6 stimulates chemotactic migration of human osteoblasts, human marrow osteoblasts, and U2-OS cells. Bone 1996, 18, 53-57. [CrossRef]

35. Einhorn, T.A. The cell and molecular biology of fracture healing. Clin. Orthop. Relat. Res. 1998, 355, S7-S21. [CrossRef]

36. Peng, H.R.; Usas, A.; Olshanski, A.; Ho, A.M.; Gearhart, B.; Cooper, G.M.; Huard, J. VEGF improves, whereas sFlt1 inhibits, BMP2-induced bone formation and bone healing through modulation of angiogenesis. J. Bone Miner. Res. 2005, 20, 2017-2027. [CrossRef] [PubMed]

37. Tan, H.B.; Giannoudis, P.V.; Boxall, S.A.; McGonagle, D.; Jones, E. The systemic influence of platelet-derived growth factors on bone marrow mesenchymal stem cells in fracture patients. BMC Med. 2015, 13, 6. [CrossRef] [PubMed]

38. Ren, G.W.; Zhao, X.; Zhang, L.Y.; Zhang, J.M.; L Huillier, A.; Ling, W.F.; Roberts, A.I.; Le, A.D.; Shi, S.; Shao, C.; et al. Inflammatory Cytokine-Induced Intercellular Adhesion Molecule-1 and Vascular Cell Adhesion Molecule-1 in Mesenchymal Stem Cells Are Critical for Immunosuppression. J. Immunol. 2010, 184, 2321-2328. [CrossRef] [PubMed]

39. Almeida, C.R.; Vasconcelos, D.P.; Goncalves, R.M.; Barbosa, M.A. Enhanced mesenchymal stromal cell recruitment via natural killer cells by incorporation of inflammatory signals in biomaterials. J. R. Soc. Interface 2012, 9, 261-271. [CrossRef] [PubMed]

40. Wang, Y.; Xu, J.; Zhang, X.; Wang, C.; Huang, Y.; Dai, K.; Zhang, X. TNF- $\alpha$-induced LRG1 promotes angiogenesis and mesenchymal stem cell migration in the subchondral bone during osteoarthritis. Cell Death Dis. 2017, 8, e2715. [CrossRef] [PubMed]

41. Kitaori, T.; Ito, H.; Schwarz, E.A.; Tsutsumi, R.; Yoshitomi, H.; Oishi, S.; Nakano, M.; Fujii, N.; Nagasawa, T.; Nakamura, T. Stromal Cell-Derived Factor 1/CXCR4 Signaling Is Critical for the Recruitment of Mesenchymal Stem Cells to the Fracture Site During Skeletal Repair in a Mouse Model. Arthritis Rheumatol. 2009, 60, 813-823. [CrossRef] [PubMed]

42. Zhang, L.; Zhou, Y.; Sun, X.Y.; Zhou, J.; Yang, P.S. CXCL12 overexpression promotes the angiogenesis potential of periodontal ligament stem cells. Sci. Rep.-UK 2017, 7, 10286. [CrossRef] [PubMed]

43. Richter, R.; Forssmann, W.; Henschler, R. Current Developments in Mobilization of Hematopoietic Stem and Progenitor Cells and Their Interaction with Niches in Bone Marrow. Transfus. Med. Hemother. 2017, 44, 151-164. [CrossRef] [PubMed]

44. Haasters, F.; Docheva, D.; Gassner, C.; Popov, C.; Bocker, W.; Mutschler, W.; Schieker, M.; Prall, W.C. Mesenchymal stem cells from osteoporotic patients reveal reduced migration and invasion upon stimulation with BMP-2 or BMP-7. Biochem. Biophys. Res. Commun. 2014, 452, 118-123. [CrossRef] [PubMed]

45. Sanghani-Kerai, A.; Coathup, M.; Samazideh, S.; Kalia, P.; Di Silvio, L.; Idowu, B.; Blunn, G. Osteoporosis and ageing affects the migration of stem cells and this is ameliorated by transfection with CXCR4. Bone Jt. Res. 2017, 6, 358-365. [CrossRef] [PubMed]

46. Nikolaou, V.S.; Efstathopoulos, N.; Kontakis, G.; Kanakaris, N.K.; Giannoudis, P.V. The influence of osteoporosis in femoral fracture healing time. Injury 2009, 40, 663-668. [CrossRef] [PubMed]

47. Naderi-Meshkin, H.; Bahrami, A.R.; Bidkhori, H.R.; Mirahmadi, M.; Ahmadiankia, N. Strategies to improve homing of mesenchymal stem cells for greater efficacy in stem cell therapy. Cell Biol. Int. 2015, 39, $23-34$. [CrossRef] [PubMed]

48. Lien, C.Y.; Chih-Yuan Ho, K.; Lee, O.K.; Blunn, G.W.; Su, Y. Restoration of bone mass and strength in glucocorticoid-treated mice by systemic transplantation of CXCR4 and cbfa-1 co-expressing mesenchymal stem cells. J. Bone Miner. Res. 2009, 24, 837-848. [CrossRef] [PubMed] 
49. Horwitz, E.M.; Prockop, D.J.; Fitzpatrick, L.A.; Koo, W.W.; Gordon, P.L.; Neel, M.; Sussman, M.; Orchard, P.; Marx, J.C.; Pyeritz, R.E.; et al. Transplantability and therapeutic effects of bone marrow-derived mesenchymal cells in children with osteogenesis imperfecta. Nat. Med. 1999, 5, 309-313. [CrossRef] [PubMed]

50. Guan, M.; Yao, W.; Liu, R.; Lam, K.S.; Nolta, J.; Jia, J.; Panganiban, B.; Meng, L.; Zhou, P.; Shahnazari, M.; et al. Directing mesenchymal stem cells to bone to augment bone formation and increase bone mass. Nat. Med. 2012, 18, 456-462. [CrossRef] [PubMed]

51. Ito, H. Chemokines in mesenchymal stem cell therapy for bone repair: A novel concept of recruiting mesenchymal stem cells and the possible cell sources. Mod. Rheumatol. 2011, 21, 113-121. [CrossRef] [PubMed]

52. Obermeyer, T.S.; Yonick, D.; Lauing, K.; Stock, S.R.; Nauer, R.; Strotman, P.; Shankar, R.; Gamelli, R.; Stover, M.; Callaci, J.J. Mesenchymal stem cells facilitate fracture repair in an alcohol-induced impaired healing model. J. Orthop. Trauma 2012, 26, 712-718. [CrossRef] [PubMed]

53. Duan, X.; Yang, L.; Zhou, Y.; Xin, Y.; Li, Q. Application of enhanced green fluorescent protein labeling technology to monitoring marrow mesenchymal stem cells migration after bone fracture. Zhongguo Xiu Fu Chong Jian Wai Ke Za Zhi 2006, 20, 102-106. [PubMed]

54. Zwingenberger, S.; Yao, Z.; Jacobi, A.; Vater, C.; Valladares, R.D.; Li, C.; Nich, C.; Rao, A.J.; Christman, J.E.; Antonios, J.K. Enhancement of BMP-2 induced bone regeneration by SDF- $1 \alpha$ mediated stem cell recruitment. Tissue Eng. Part A 2014, 20, 810-818. [CrossRef] [PubMed]

55. Chen, G.; Fang, T.; Qi, Y.; Yin, X.; Di, T.; Feng, G.; Lei, Z.; Zhang, Y.; Huang, Z. Combined Use of Mesenchymal Stromal Cell Sheet Transplantation and Local Injection of SDF-1 for Bone Repair in a Rat Nonunion Model. Cell Transplant. 2016, 25, 1801-1817. [CrossRef] [PubMed]

56. Xu, L.; Huang, S.; Hou, Y.; Liu, Y.; Ni, M.; Meng, F.; Wang, K.; Rui, Y.; Jiang, X.; Li, G. Sox11-modified mesenchymal stem cells (MSCs) accelerate bone fracture healing: Sox11 regulates differentiation and migration of MSCs. FASEB J. 2015, 29, 1143-1152. [CrossRef] [PubMed]

57. Park, M.J.; Lee, S.H.; Moon, S.J.; Lee, J.A.; Lee, E.J.; Kim, E.K.; Park, J.S.; Lee, J.; Min, J.K.; Kim, S.J.; et al. Overexpression of soluble RAGE in mesenchymal stem cells enhances their immunoregulatory potential for cellular therapy in autoimmune arthritis. Sci. Rep. 2016, 6, 35933. [CrossRef] [PubMed]

58. Han, N.; Zhang, F.; Li, G.; Zhang, X.; Lin, X.; Yang, H.; Wang, L.; Cao, Y.; Du, J.; Fan, Z. Local application of IGFBP5 protein enhanced periodontal tissue regeneration via increasing the migration, cell proliferation and osteo/dentinogenic differentiation of mesenchymal stem cells in an inflammatory niche. Stem Cell Res. Ther. 2017, 8, 210. [CrossRef] [PubMed]

59. Sheyn, D.; Shapiro, G.; Tawackoli, W.; Jun, D.S.; Koh, Y.; Kang, K.B.; Su, S.; Da, X.; Ben-David, S.; Bez, M.; et al. PTH Induces Systemically Administered Mesenchymal Stem Cells to Migrate to and Regenerate Spine Injuries. Mol. Ther. 2016, 24, 318-330. [CrossRef] [PubMed]

60. Sekiya, I.; Ojima, M.; Suzuki, S.; Yamaga, M.; Horie, M.; Koga, H.; Tsuji, K.; Miyaguchi, K.; Ogishima, S.; Tanaka, H.; et al. Human mesenchymal stem cells in synovial fluid increase in the knee with degenerated cartilage and osteoarthritis. J. Orthop. Res. 2012, 30, 943-949. [CrossRef] [PubMed]

61. Koyama, N.; Okubo, Y.; Nakao, K.; Osawa, K.; Fujimura, K.; Bessho, K. Pluripotency of mesenchymal cells derived from synovial fluid in patients with temporomandibular joint disorder. Life Sci. 2011, 89, 741-747. [CrossRef] [PubMed]

62. Zhen, G.; Wen, C.; Jia, X.; Li, Y.; Crane, J.L.; Mears, S.C.; Askin, F.B.; Frassica, F.J.; Chang, W.; Yao, J.; et al. Inhibition of TGF- $\beta$ signaling in mesenchymal stem cells of subchondral bone attenuates osteoarthritis. Nat. Med. 2013, 19, 704-712. [CrossRef] [PubMed]

63. De Becker, A.; Riet, I.V. Homing and migration of mesenchymal stromal cells: How to improve the efficacy of cell therapy? World J. Stem Cells 2016, 8, 73-87. [CrossRef] [PubMed]

64. Wu, Y.; Zhao, R.C. The role of chemokines in mesenchymal stem cell homing to myocardium. Stem Cell Rev. 2012, 8, 243-250. [CrossRef] [PubMed]

65. Moll, N.M.; Ransohoff, R.M. CXCL12 and CXCR4 in bone marrow physiology. Expert Rev. Hematol. 2010, 3, 315-322. [CrossRef] [PubMed]

66. Honczarenko, M.; Le, Y.; Swierkowski, M.; Ghiran, I.; Glodek, A.M.; Silberstein, L.E. Human bone marrow stromal cells express a distinct set of biologically functional chemokine receptors. Stem Cells 2006, 24, 1030-1041. [CrossRef] [PubMed] 
67. Shi, M.; Li, J.; Liao, L.; Chen, B.; Li, B.; Chen, L.; Jia, H.; Zhao, R.C. Regulation of CXCR4 expression in human mesenchymal stem cells by cytokine treatment: Role in homing efficiency in NOD/SCID mice. Haematologica 2007, 92, 897-904. [CrossRef] [PubMed]

68. Gao, H.; Priebe, W.; Glod, J.; Banerjee, D. Activation of signal transducers and activators of transcription 3 and focal adhesion kinase by stromal cell-derived factor 1 is required for migration of human mesenchymal stem cells in response to tumor cell-conditioned medium. Stem Cells 2009, 27, 857-865. [CrossRef] [PubMed]

69. Kim, Y.S.; Noh, M.Y.; Kim, J.Y.; Yu, H.J.; Kim, K.S.; Kim, S.H.; Koh, S.H. Direct GSK-3ß inhibition enhances mesenchymal stromal cell migration by increasing expression of beta-PIX and CXCR4. Mol. Neurobiol. 2013, 47, 811-820. [CrossRef] [PubMed]

70. Annabi, B.; Lee, Y.T.; Turcotte, S.; Naud, E.; Desrosiers, R.R.; Champagne, M.; Eliopoulos, N.; Galipeau, J.; Béliveau, R. Hypoxia promotes murine bone-marrow-derived stromal cell migration and tube formation. Stem Cells 2003, 21, 337-347. [CrossRef] [PubMed]

71. Liu, H.; Xue, W.; Ge, G.; Luo, X.; Li, Y.; Xiang, H.; Ding, X.; Tian, P.; Tian, X. Hypoxic preconditioning advances CXCR4 and CXCR7 expression by activating HIF-1 $\alpha$ in MSCs. Biochem. Biophys. Res. Commun. 2010, 401, 509-515. [CrossRef] [PubMed]

72. Tsai, L.K.; Wang, Z.; Munasinghe, J.; Leng, Y.; Leeds, P.; Chuang, D.M. Mesenchymal stem cells primed with valproate and lithium robustly migrate to infarcted regions and facilitate recovery in a stroke model. Stroke 2011, 42, 2932-2939. [CrossRef] [PubMed]

73. Najafi, R.; Sharifi, A.M. Deferoxamine preconditioning potentiates mesenchymal stem cell homing in vitro and in streptozotocin-diabetic rats. Expert Opin. Biol. Ther. 2013, 13, 959-972. [CrossRef] [PubMed]

74. Knowles, H.J.; Tian, Y.M.; Mole, D.R.; Harris, A.L. Novel mechanism of action for hydralazine: Induction of hypoxia-inducible factor- $1 \alpha$, vascular endothelial growth factor, and angiogenesis by inhibition of prolyl hydroxylases. Circ. Res. 2004, 95, 162-169. [CrossRef] [PubMed]

75. Hoenig, M.R.; Bianchi, C.; Sellke, F.W. Hypoxia inducible factor- $1 \alpha$, endothelial progenitor cells, monocytes, cardiovascular risk, wound healing, cobalt and hydralazine: A unifying hypothesis. Curr. Drug Targets 2008, 9, 422-435. [CrossRef] [PubMed]

76. Yu, X.; Lu, C.; Liu, H.; Rao, S.; Cai, J.; Liu, S.; Kriegel, A.J.; Greene, A.S.; Liang, M.; Ding, X. Hypoxic preconditioning with cobalt of bone marrow mesenchymal stem cells improves cell migration and enhances therapy for treatment of ischemic acute kidney injury. PLoS ONE 2013, 8, e62703. [CrossRef] [PubMed]

77. Bobis-Wozowicz, S.; Miekus, K.; Wybieralska, E.; Jarocha, D.; Zawisz, A.; Madeja, Z.; Majka, M. Genetically modified adipose tissue-derived mesenchymal stem cells overexpressing CXCR4 display increased motility, invasiveness, and homing to bone marrow of NOD/SCID mice. Exp. Hematol. 2011, 39, 686-696. [CrossRef] [PubMed]

78. Kumar, S.; Ponnazhagan, S. Bone homing of mesenchymal stem cells by ectopic $\alpha 4$ integrin expression. FASEB J. 2007, 21, 3917-3927. [CrossRef] [PubMed]

79. Wiehe, J.M.; Kaya, Z.; Homann, J.M.; Wohrle, J.; Vogt, K.; Nguyen, T.; Rottbauer, W.; Torzewski, J.; Fekete, N.; Rojewski, M.; et al. GMP-adapted overexpression of CXCR4 in human mesenchymal stem cells for cardiac repair. Int. J. Cardiol. 2013, 167, 2073-2081. [CrossRef] [PubMed]

80. Hu, X.; Dai, S.; Wu, W.J.; Tan, W.; Zhu, X.; Mu, J.; Guo, Y.; Bolli, R.; Rokosh, G. Stromal cell derived factor-1 $\alpha$ confers protection against myocardial ischemia/reperfusion injury: Role of the cardiac stromal cell derived factor- $1 \alpha$ CXCR4 axis. Circulation 2007, 116, 654-663. [CrossRef] [PubMed]

81. Penn, M.S.; Mendelsohn, F.O.; Schaer, G.L.; Sherman, W.; Farr, M.; Pastore, J.; Rouy, D.; Clemens, R.; Aras, R.; Losordo, D.W. An open-label dose escalation study to evaluate the safety of administration of nonviral stromal cell-derived factor-1 plasmid to treat symptomatic ischemic heart failure. Circ. Res. 2013, 112, 816-825. [CrossRef] [PubMed]

82. Fujii, H.; Li, S.H.; Wu, J.; Miyagi, Y.; Yau, T.M.; Rakowski, H.; Egashira, K.; Guo, J.; Weisel, R.D.; Li, R.K. Repeated and targeted transfer of angiogenic plasmids into the infarcted rat heart via ultrasound targeted microbubble destruction enhances cardiac repair. Eur. Heart J. 2011, 32, 2075-2084. [CrossRef] [PubMed]

83. Abbott, J.D.; Huang, Y.; Liu, D.; Hickey, R.; Krause, D.S.; Giordano, F.J. Stromal cell-derived factor-1 $\alpha$ plays a critical role in stem cell recruitment to the heart after myocardial infarction but is not sufficient to induce homing in the absence of injury. Circulation 2004, 110, 3300-3305. [CrossRef] [PubMed] 
84. Askari, A.T.; Unzek, S.; Popovic, Z.B.; Goldman, C.K.; Forudi, F.; Kiedrowski, M.; Rovner, A.; Ellis, S.G.; Thomas, J.D.; DiCorleto, P.E.; et al. Effect of stromal-cell-derived factor 1 on stem-cell homing and tissue regeneration in ischaemic cardiomyopathy. Lancet 2003, 362, 697-703. [CrossRef]

85. Zhang, G.; Nakamura, Y.; Wang, X.; Hu, Q.; Suggs, L.J.; Zhang, J. Controlled release of stromal cell-derived factor- $1 \alpha$ in situ increases c-kit+ cell homing to the infarcted heart. Tissue Eng. 2007, 13, 2063-2071. [CrossRef] [PubMed]

86. Dong, Y.; Liu, H.; Zhang, X.; Xu, F.; Qin, L.; Cheng, P.; Huang, H.; Guo, F.; Yang, Q.; Chen, A. Inhibition of SDF-1 $\alpha$ /CXCR4 Signalling in Subchondral Bone Attenuates Post-Traumatic Osteoarthritis. Int. J. Mol. Sci. 2016, 17, 943. [CrossRef] [PubMed]

87. Zhao, T.; Zhang, D.; Millard, R.W.; Ashraf, M.; Wang, Y. Stem cell homing and angiomyogenesis in transplanted hearts are enhanced by combined intramyocardial SDF-1 $\alpha$ delivery and endogenous cytokine signaling. Am. J. Physiol. Heart Circ. Physiol. 2009, 296, H976-H986. [CrossRef] [PubMed]

88. Blumenthal, B.; Poppe, A.; Golsong, P.; Blanke, P.; Rylski, B.; Beyersdorf, F.; Schlensak, C.; Siepe, M. Functional regeneration of ischemic myocardium by transplanted cells overexpressing stromal cell-derived factor-1 (SDF-1): Intramyocardial injection versus scaffold-based application. Eur. J. Cardiothorac. Surg. 2011, 40, e135-e141. [CrossRef] [PubMed]

89. Ko, I.K.; Kean, T.J.; Dennis, J.E. Targeting mesenchymal stem cells to activated endothelial cells. Biomaterials 2009, 30, 3702-3710. [CrossRef] [PubMed]

90. Sackstein, R.; Merzaban, J.S.; Cain, D.W.; Dagia, N.M.; Spencer, J.A.; Lin, C.P.; Wohlgemuth, R. Ex vivo glycan engineering of CD44 programs human multipotent mesenchymal stromal cell trafficking to bone. Nat. Med. 2008, 14, 181-187. [CrossRef] [PubMed]

91. Ko, I.K.; Kim, B.G.; Awadallah, A.; Mikulan, J.; Lin, P.; Letterio, J.J.; Dennis, J.E. Targeting improves MSC treatment of inflammatory bowel disease. Mol. Ther. 2010, 18, 1365-1372. [CrossRef] [PubMed]

92. Lin, F.; Zhang, W.; Xue, D.; Zhu, T.; Li, J.; Chen, E.; Yao, X.; Pan, Z. Signaling pathways involved in the effects of HMGB1 on mesenchymal stem cell migration and osteoblastic differentiation. Int. J. Mol. Med. 2016, 37, 789-797. [CrossRef] [PubMed]

93. Xian, L.; Wu, X.; Pang, L.; Lou, M.; Rosen, C.J.; Qiu, T.; Crane, J.; Frassica, F.; Zhang, L.; Rodriguez, J.P.; et al. Matrix IGF-1 maintains bone mass by activation of mTOR in mesenchymal stem cells. Nat. Med. 2012, 18, 1095-1101. [CrossRef] [PubMed]

94. Hinshaw, J.E. Dynamin and its role in membrane fission. Annu. Rev. Cell Dev. Biol. 2000, 16, 483-519. [CrossRef] [PubMed]

95. Ochoa, G.C.; Slepnev, V.I.; Neff, L.; Ringstad, N.; Takei, K.; Daniell, L.; Kim, W.; Cao, H.; McNiven, M.; Baron, R.; et al. A functional link between dynamin and the actin cytoskeleton at podosomes. J. Cell Biol. 2000, 150, 377-389. [CrossRef] [PubMed]

96. Kubo, T.; Shiga, T.; Hashimoto, J.; Yoshioka, M.; Honjo, H.; Urabe, M.; Kitajima, I.; Semba, I.; Hirasawa, Y. Osteoporosis influences the late period of fracture healing in a rat model prepared by ovariectomy and low calcium diet. J. Steroid Biochem. 1999, 68, 197-202. [CrossRef]

97. Zhao, J.; Zhang, N.; Prestwich, G.D.; Wen, X. Recruitment of endogenous stem cells for tissue repair. Macromol. Biosci. 2008, 8, 836-842. [CrossRef] [PubMed]

(C) 2018 by the authors. Licensee MDPI, Basel, Switzerland. This article is an open access article distributed under the terms and conditions of the Creative Commons Attribution (CC BY) license (http://creativecommons.org/licenses/by/4.0/). 